\title{
UDK 692.232
}

\author{
A. V. RADKEVYCH ${ }^{1 *}$, K. M. NETESA ${ }^{2 *}$ \\ ${ }^{1 *}$ Dep. «Build Production and Geodesy», Dnipropetrovsk National University of Railway Transport named after \\ Academician V. Lazaryan, Lazaryan St., 2, Dnipropetrovsk, Ukraine, 49010, +38 (098) 3078144 , \\ e-mail KVP@DSST.gov.ua, ORCID 0000-0001-6325-8517 \\ ${ }^{2 *}$ Dep. «Build Production and Geodesy», Dnipropetrovsk National University of Railway Transport named after \\ Academician V. Lazaryan, Lazaryan St., 2, Dnipropetrovsk, Ukraine, 49010, +38 (063) 49296 17, \\ e-mail netesakostia@meta.ua. ORCID 0000-0002-4087-5552.
}

\section{ASPECTS DEFINITION OF RELIABILITY EVALUATION FACADE SYSTEMS FROM THE VIEW POINT OF EUROCODE}

Purpose. This paper is devoted to the definition of the most rational technique of reliability evaluation of facade systems of multistoried residential buildings with using the experience of buildings construction and operation abroad. The subject is also focused on defining the parameters of materials and facade systems, the improvement of which can increase the reliability and durability of facade systems of multistoried residential buildings, as well as cut the cost of their operation. Methodology. A comparative analysis of the operating experience of various types of facade systems in Ukraine and abroad based on the data of different authors was conducted. The analysis of the impact of external factors on facade systems with the subsequent comparison of methods for assessing the reliability of facades according to the criteria stated in the Eurocode was carried out as well as the selection of parameters that determine the reliability and durability of facade systems. Findings. Authors have performed researches of evaluation methods of organizational and technological reliability and durability of modern facade systems. It was identified the cause of the failure of facade systems. It is offered the ways of materials improvement of facade systems, and constructional and organization-technological decisions on the structure of facade systems. Methods of increase of reliability and durability of front systems were defined. Originality. The most rational technique of reliability evaluation of facade systems considering requirements of Eurocode in questions structural design was defined. Practical value. Improvement of evaluating methods for organizational-technological reliability of facade systems of multistoried residential buildings will predict more accurately the lifetime of enclosures. Using the methods described in the Eurocodes, to determine the reliability and durability of the facade systems will provide the general criteria for the building structures design in Ukraine and Europe, as well as facilitate the exchange of experience in the construction and operation of buildings between the countries of Europe. An analysis of the causes of failures of facades enables to determine the directions of improving the properties of the materials used for the manufacture of facade elements structures as well as engineering and technological solutions of applied facade systems.

Keywords: facade system; reliability; durability; operation; failure

\section{Introduction}

The analysis of modern construction and operation of multistoried residential buildings in Ukraine and abroad showed that two main front systems are most often applied: the hinged ventilated facade (HVF) and facade plaster system (external insulated render system) $[1,6,7,10]$. The widespread use facade systems of these types, the problem of foresight in reliability are not solved. It does impossible timely carrying out necessary preventive or maintenance actions therefore failure of facade systems lead to decrease in their durability. To restore the original parameter of resistance the heat transmission of such facades necessary to carry out extensive repairs are necessary, resulting in increased cost of its operation [1, 5-7].
Research of construction experience and operation of multistoried residential buildings showed that the applied facade systems of different types differ in a considerable constructive variety. For the purpose of facade system depreciation, carried out the different approaches to the solution of the opposition problem of environmental effect. A significant amount of facade systems elements does not allow estimating rather precisely its reliability by traditional methods $[7,9,10]$. This is due to the complexity of drawing up an analytical model of facade system works, which takes into account changes in material properties with time, deviations from design position of facades elements, violations device technology in the construction process, as well as possible deviations from the 
accepted analytical model of load and the impact of environmental effect to the facade system. At projected lifetime 25-50 years, crippling surface of facade systems of «external insulated render system» type detected after 3-5 years of their operation, and in some cases, in 2-3 years. Curtain wall systems at the projected lifetime in 20-30 years operated for 40-50 years. It is known data about the work of curtain wall systems for over 100 years without a failure of the identified, and destruction $[5-7,11]$. Thus, the working techniques allowing to estimate authentically reliability of front systems and precisely to predict the term of their service, by domestic scientists it was not conducted.

\section{Purpose}

The aim of the research was to determine the factors causing failures of different types of facade systems, and improving the system of assessing the reliability of building designs that would reliably predict the service life of various types of facade systems.

\section{Methodology}

The method consists in:

- definition of failure causes of work of facade systems of different types;

- analysis of experience of the device and operation of facade systems of residential multistoried buildings;

- comparison of existing methods for assessing the reliability of structures and their compliance with the Eurocodes.

\section{Originality}

One of the basic constructive elements of the building providing its effective operation throughout all service life is the facade system. The modern facade systems provide building protection against action of external environment factors and allow supporting comfortable facilities for being people inside. In such case to the outside part of facade system affects the largest number of destructive factors such as:

- effect of precipitation (rain, snow, fog), often - with a mixture of acids, causing the rapid destruction of coatings;

- wind loading, causing a deviation from the facade elements from design position;
- section gradient of temperatures which in combination with soaking of facade system lead to structural failure of walls and violation of the mode of operation of the building;

- insolation, which causes heating facade elements and can lead to changes in the properties of varnish-and-paint coatings and accelerate its destruction.

To ensure the normal building operation during the base period of facade system must have a high durability, maintainability, reliability and storage ability, have low cost and good installing process ability. It will lead to lowering of the material inputs on carrying out repair work on restoration of a facade and will allow reducing the cost of building operation. The carrying-out of requirements of facade system significance allows reducing the possibility of technological obsolescence of the building. The selecting a facade system that satisfies all of the above conditions is possible by comparing the different types reliability of facade systems, which will allow to predict the service life, as well as the cost and frequency of necessary repairs to restore the facade systems [2-7, 9].

Among curtain wall systems with a ventilated air-gap clearance from one of the most applicable is a facade system with ashlaring of ceramic granite (Fig. 1).

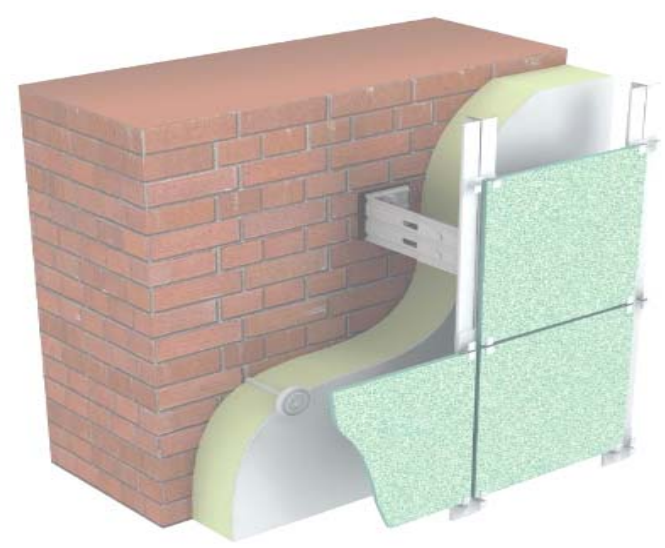

Fig. 1. Curtain wall systems with ashlaring of ceramic granite

This facade system present itself a system of vertical channels which are using metallically fasteners and anchor connections firmly attached to the walls of the building and the presence of capping ensures reliable fastening of facing tile from ceramic granite. Thus, protection of the 
facade system supporting parts against corrosion provided with appliance of corrosion-resistant alloys or zinc coverings.

For support of a wall heat-insulating characteristics of the building uses the mineral wool board which fasten to a wall with using the dished anchors. The air device gap of $5-7 \mathrm{~cm}$ provides deleting moisture from an insulant and prevent of its watering. Thus existence of air gap can lead to distribution of the fire in facade system on a building wall that results in need of use only of a nonflammable insulant $[2-9,12,14]$.

Facade plaster system of «external insulated render system» (Fig. 2) ) is a system of several types of coatings, which main task to reduce the thermal conductivity of the wall and prevent penetration of moisture in the insulation layer. Insulation is minral-cottone or polystyrene slabes is fastened to the building wall by means of dished anchors. Above the insulation is executed plaster, in the middle of which sink grease alkali prof polymer network, whose task is to ensure the strength of the plaster layer. On the top of the layer of plaster, protecting the insulation against mechanical damage runs waterproof paint and lightproof stain.

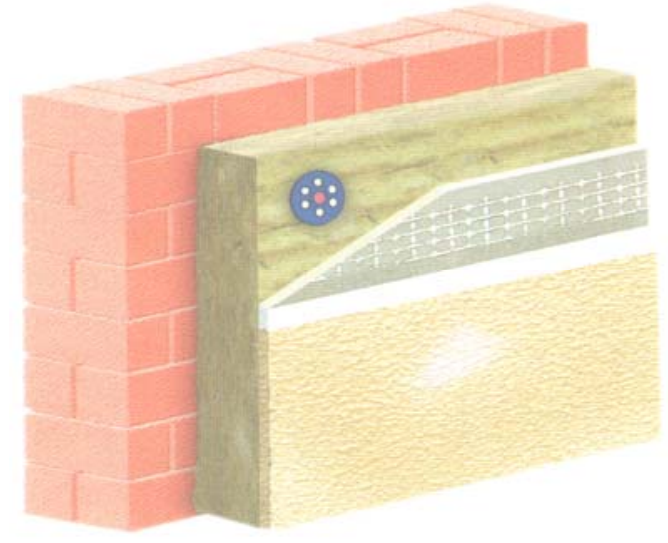

Fig. 2. Facade system of «external insulated render system»

Since July 1, 2014 in Ukraine enacted Eurocodes operating in parallel with national regulations. DSTU NB B.1. 2-13: 2008 «Basis of structural design», according to EN 1990: 2002 and takes into account the experience of the construction and operation of residential and public buildings in Europe, where the facade system of the «external insulated render system» type and curtain wall systems appeared much earlier than in
Ukraine. This has allowed checking in practice the results of evaluating the reliability and durability of the building structures in general, and facade systems in particular $[1,3,7]$.

The conducted researches of facade systems showed that in case of the declared service life in 25-30 years the «external insulated render system» facades require preventive repair in 5-7 years of operation. At this age, corrupting or plaster blanket peelings and color buckling are watched. Coloration of a facade allows prolonging operation for the next 5-7 years, and at the age of 14-18 years, it is necessary to perform works on plaster layer restoration. Necessity of carrying out the repair work is connected to that the paint coat quickly fails from influence of sunshine then the plaster coat is sated with water during precipitates. In case of the subsequent modes of freezing defrosting the water which got to plaster pores destroys it, and with each cycle penetration depth of moisture in plaster and the total area of the damaged facade increases $[1,11,13,14]$.

The hinged ventilated facades with ashlaring of ceramic granite have other pattern of corrupting. At the declared service life in 25-50 years the real durability of such facades systems comes nearer to settlement and need of repair work arises only in local places, most often - as a result of mechanical damage of facing tile. The facing ceramic granite tile made with a high pressure $\left(4-5 \mathrm{kN} / \mathrm{cm}^{2}\right)$ and at a temperature of $1200-1300{ }^{\circ} \mathrm{C}$. As a result the compact structure of a tile has low water absorption - not higher than $0,1 \%$. During rainfall water, flowing down on ceramic granite does not get into its structure, and the subsequent fluctuations of temperature upon transition of a freezing point cannot cause destruction of a tile blanket. It gives the chance to apply a tile of $8-16 \mathrm{~mm}$ thickness, avoiding weighting of a facade. Destructions of such facade system (in the absence of mistakes at a stage of design and installation) result from corrosion of the bearing profiles. Destructions of such facade system (in the absence of mistakes at a stage of design and installation) result from corrosion of the high-lift profile. During inspection of facade system with facing porcelain tile at the age of 7 years, revealed damages of ceramic granite tile only at the level of the first floor because of blows, and on the galvanized high-lift profile there were white spots testifying to corrosion initial stage of zinc covering. Impact of rainfall and 
sunlight did not affect a ceramic granite tile in any way - damages of structure are higher than the first floor was not revealed [7, 10-12].

According to DSTU N B B.1. 2-13:2008, reliability is an ability of a construction or construction element to meet certain requirements throughout all service life for which they were designed. Organizational and technological reliability has to cover safety, operational reliability and durability of the construction. It will allow considering requirements of technological effectiveness of the device and mounting of facade system that reduces probability of occurrence of error made at a stage of facade erection. The facade system longevity directly depends not only on its resistance to influence of external factors, but also on possibility of fast carrying out diagnostics and repair with restoration of original properties of system in general.

Research of facade system of «external insulated render system» type in order to identify the optimal time and volume of necessary repairs is difficult because of the design features of the system. Without compromising the integrity of paint and plaster it is impossible to assess the condition of the insulation. Partial replacement of plaster or paint layer in the ground damages violates the relationship between the elements of the facade system. Perform painting facade system when the color layer is broken, but the destruction of the plaster had not yet begun, it is not always possible because of the diagnosis difficulties of the state of the facade system. As a result of further plaster peeling primarily occurs in the places where they perform local plastering damaged areas. In contrast to the «external insulated render system» facade, curtain wall systems with ceramic granite allows you to survey the any facade site at any time, and if necessary, perform removal and replacement of individual tiles and capping or more high-lift profile [1, 2, 4, 10-14].

Given the pattern of destruction and the causes of failures of different types of facade systems, it is reasonable to assess the organizational and technological reliability facade systems that element or elements system, the disruption of which causes damage to the facade system in whole. For «external insulated render system» facades should highlight such elements:

- a surface layer of paint, which most often is destroyed by the action of sunlight or has water permeability, which leads to further soak the plaster and paint peeling;

- protective layer of plaster, lack of thickness often leads to mechanical failure as a result of wind or rain.

Reliability analysis of anchor connections providing fastening insulation to the outer wall of the building is not required, as the strength of the currently used compounds sufficient anchor: with the technology of the tooling facade system of the «external insulated render system» type of insulation peeling is not observed. Also, there is no need to study the effect of the thickness of the plaster layer facade system on its overall reliability. Analysis of the causes of destruction facade systems with plaster layer of different thickness showed that the reliability of the facade system has the greatest impact is not the thickness of plaster and waterresistant exterior paint. Manufacturability requirements facade configuration of «external insulated render system» type should be taken into account at the design building stage when compared to systems of various manufacturers.

In some cases, the cause of facade paint destruction was the plaster prominent structure (the facade type «rustic-textured coating»). In the ravine of such facade the dust settles, and the ingress of atmospheric moisture, combined with warming sunlight creates a favorable environment for the development of both bacteria and bluegreen algae. As a result of their activity the paint coat fails that involves plaster damage. To delete from all dimples of a microorganisms colony and to protect a relief surface of a facade from intrusion of dust it isn't possible. In the case of a smooth plaster structure the growth of microorganisms was not observed. That is why the structure of the surface is not included in the parameters for determining the reliability: should use or facade systems with a smooth surface, or preventative paint as often as every $4-5$ years $[1,6$, 8, 10-11].

Curtain wall system is destroyed only in case of violation the high-lift profile system. In this case, the elements for which you want to determine the reliability can be the following:

- anchor junction fastening element of facade system with curtain wall of the building;

- the system bearing elements of a suspended facade (including mounting clamps), which damage as a result of the corrosive effects of water vapor (often - the impact of acids present in 


\section{the atmosphere).}

In this case the need to assess the reliability of the anchor connections due to the fact that the lining of ceramic granite tile is not hermetical. Construction technology suspended facade with ceramic granite facing provides an equipment gap between the individual tiles. As a result in case of wind impact on a facade the system of the bearing profiles experiences bending loads, and the pulling-out efforts are transferred to anchor connections of fasteners with a wall of the building. Researches of reliability of facade ceramic granite tile it isn't supposed as showed researches, sunshine and atmospheric actions have practically no impact on the ceramic granite tile conforming to the modern standards. The solid surface of a ceramic granite tile, steady against abrasion-resistant remains smooth for all period of operation that provides persistence of physical configuration and absence of opportunities for development of germ culture, unlike front systems of «external insulated render system» type. The choice of fixing tiles from the viewpoint of processability of the tool curtain wall systems should be carried out at the design stage by comparison when determining the reliability of facade systems from different manufacturers.

In case of insufficient processability the most reliable facade system is necessary to develop a set of measures that increase the adaptability of the process of installation of the facade system to reduce the likelihood of errors made during the construction of the building and the tools of facade system.

\section{Originality and practical value}

The factors that determine the reliability and durability of facade systems are investigated. It is found the perspective of appliance prospects suspended and the "external insulated render system» facades. Problems of carrying out scheduled maintenance on restoration of facades with a thin plaster layer are defined.

Determination of reliability of modern facade systems of multi-storey residential buildings will more accurately predict the duration of their uptime, determine the optimal time for repair and restoration work, reduce maintenance costs of buildings, and in the long term to increase the lifetime of maintenance-free facade systems through the use of materials, more relevant the effects of destructive factors.

\section{Conclusions}

Using the methods and principles set forth in the Eurocodes, to determine the organizational and process reliability for various types of facade systems. Research of model the influence of the factors causing failures of facades and determination of their influence on the general reliability of facade system allows to define exact periods of carrying out necessary repair or recovery work, therefore - to lower costs of operation of buildings. Numerical determination of reliability of facade systems will reveal parameters of the facades of materials applied to the device which the first decay under the influence of external factors. This will allow the subsequent development of technologies used to improve building materials and increase the period of maintenance-free operation of facade systems.

\section{LIST OF REFERENCE LINKS}

1. Гагарин, В. Г. Теплоизоляционные фасады с тонким штукатурным слоем / В. Г. Гагарин // АВОК. - 2007. - № 6. - С. 82-103.

2. Грановский, А. В. О методике испытаний анкеров на вырыв из различных стеновых материалов и возможных областях их применения / А. В. Грановский, Д. А. Киселев // Жилищ. стрво. -2010 . - № 2. - С. 7-8.

3. ДСТУ-Н Б В.1.2-13:2008. Настанова. Основи проектування конструкцій. - На заміну ENV 1991-1:1994 ; надано чинності 2009-07-01. Київ : Мінрегіонбуд України, 2009. - 81 с.

4. Дудкина, В. В. Адгезионная прочность никелевых и цинковых покрытий с медной основой, электроосажденных в условиях внешней стимуляции лазерным излучением / В. В. Дудкина // Наука та прогрес трансп. Вісн. Дніпропетр. нац. ун-ту залізн. трансп. - 2013. - № 2 (44). - C. 83-91. doi: 10.15802/stp2013-/12245.

5. Емельянова, В. А. Оптимизированная конструкция навесного вентилируемого фасада / В. А. Емельянова, Д. В. Немова, Д. Р. Мифтахова // Инж.-строит. журн. - 2014. - № 6 (50). C. 53-66.

6. Еноткина, С. Эксплуатация многослойных ограждающих конструкций / С. Еноткина // Молодой ученый. - 2011. - № 6 (29). - С. 49-52. 
7. Мотяев, М. А. Азбука навесных фасадов с воздушным зазором / М. А. Мотяев. - Юкон Инжиниринг, 2005. - 104 с.

8. Орлович, Р. Б. О работе анкеров в многослойных ограждающих конструкциях с наружным кирпичным слоем / Р. Б. Орлович, Н. М. Рубцов, С. С. Зимин // Инж.-строит. журн. - 2013. - № 1 (36). - С. 3-11.

9. Терешкова, А. В. Исследование деформативности и совершенствование конструктивных решений элементов каркаса фасадных систем с вентилируемым воздушным зазором : дис... канд. техн. наук : 05.23.01 / Терешкова Александра Викторовна : Сиб. федер. ун-т. - Красноярск, 2007. - 233 с. - Библиогр.: с. 148-158.

10. Туснина, О. А. Теплотехнические свойства различных конструктивных систем навесных вентилируемых фасадов / О. А. Туснина, А. А. Емельянов, В. М. Туснина // Инж.-строит. журн. - 2013. - № 8 (43). - С. 54-63.

\section{А. В. РАДКЕВИЧ ${ }^{1 *}$, К. М. НЕТЕСА ${ }^{2 *}$}

11. Щербак, А. С. Исследование свойств современных теплоизоляционных материалов / А. С. Щербак // Наука та прогрес трансп. Вісн. Дніпропетр. нац. ун-ту залізн. трансп. - 2013. - № 2 (44). C. 136-143. doi: 10.15802/stp2013-/12993.

12. Analytical assessment of thermal performance of a ventilated glazed facade system / M. Dagnall, A. Window, A. Leung, D. Thompson // Proc. of Building Simulation : $12^{\text {th }}$ Conf. of Intern. Building Performance Simulation Association (14.11.16.11.2011). - Sydney, 2011. - P. 808-815.

13. Ciampi, M. On the thermal behavior of ventilated facades and roofs / M. Champi, F. Leccese, G. Tuoni // La Termotecnica. - 2002. - № 1. - P. 87-97.

14. Ciampi, M. Some thermal parameters influence on the energy performance of rhe ventilated walls / M. Champi, F. Leccese, G. Tuoni // Proc. of $20^{\text {th }}$ UIT National Heart Transfer Conf. (27.06.29.06.2002). - Maratea, 2002. - P. 357-362.

\footnotetext{
${ }^{1 *}$ Каф. «Будівельне виробництво та геодезія», Дніпропетровський національний університет залізничного транспорту імені академіка В. Лазаряна, вул. Лазаряна, 2, Дніпропетровськ, Україна, 49010, тел. +38 (098) 3078144 , ел. пошта KVP@DSST.gov.ua, ORCID ID: 0000-0001-6325-8517

$2^{2 *}$ Каф. «Будівельне виробництво та геодезія», Дніпропетровський національний університет залізничного транспорту імені академіка В. Лазаряна, вул. Лазаряна, 2, Дніпропетровськ, Україна, 49010, тел. +38 (063) 49296 17, ел. пошта netesakostia@meta.ua, ORCID ID: 0000-0002-4087-5552
}

\section{ВИЗНАЧЕННЯ АСПЕКТІВ ОЦІНЮВАННЯ НАДІЙНОСТІ ФАСАДНИХ СИСТЕМ IЗ TOЧКИ ЗОРУ EUROCODE}

Мета. Робота присвячена визначенню найбільш раціональної методики оцінки надійності фасадних систем багатоповерхових житлових будівель із використанням досвіду будівництва та експлуатації будівель за кордоном. Також передбачається визначення параметрів матеріалів фасадних систем, покращення якостей яких дозволить підвищити надійність, довговічність фасадних систем багатоповерхових житлових будівель та знизити вартість їх експлуатації. Методика. В дослідженні проведений порівняльний аналіз досвіду експлуатації фасадних систем різних типів в Україні та за кордоном на основі даних різних авторів. Був зроблений аналіз впливів зовнішніх факторів на фасадні системи з наступним порівнянням методик оцінки надійності фасадів за критеріями, викладеними в Eurocode, і виділенням параметрів, що визначають надійність та довговічність фасадних систем. Результати. Авторами проведено дослідження методів оцінки організаційно-технологічної надійності та довговічності сучасних фасадних систем. Було виявлено причини виникнення відмов фасадних систем. Запропоновані шляхи вдосконалення матеріалів фасадних систем, а також конструкційних та організаційно-технологічних рішень із влаштування фасадних систем. Визначені методи підвищення надійності та довговічності фасадних систем. Наукова новизна. Визначена найбільш раціональна методика оцінки надійності фасадних систем, що враховує вимоги Eurocode в питаннях проектування будівельних конструкцій. Практична значимість. Вдосконалення методів оцінювання організаційно-технологічної надійності фасадних систем багатоповерхових житлових будівель дозволить точніше прогнозувати термін роботи огороджуючих конструкцій будівель. Використання методик, викладених в Eurocode, для визначення надійності та довговічності фасадних систем дозволить забезпечити загальні критерії проектування будівельних конструкцій в Україні та в країнах Свропи, а також полегшити обмін досвідом будівництва та експлуатації будівель між країнами Європи. Аналіз причин виникнення відмов фасадів дає можливість визначити напрямки вдосконалення якостей матеріалів, що використовуються для виготовлення елементів фасадних конструкцій, а також конструкційних та технологічних рішень використовуваних фасадних систем. 
Ключові слова: фасадна система; надійність; довговічність; експлуатація; відмова

\title{
А. В. РАДКЕВИЧ ${ }^{1 *}$, К. Н. НЕТЕСА ${ }^{2 *}$
}

\begin{abstract}
${ }^{1 *}$ Каф. «Строительное производство и геодезия», Днепропетровский национальный университет железнодорожного транспорта имени академика В. Лазаряна, ул. Лазаряна, 2, Днепропетровск, Украина, 49010, тел. +38 (098) 30781 44, эл. почта KVP@DSST.gov.ua, ORCID 0000-0001-6325-8517

${ }^{2 *}$ Каф. «Строительное производство и геодезия», Днепропетровский национальный университет железнодорожного транспорта имени академика В. Лазаряна, ул. Лазаряна, 2, Днепропетровск, Украина, 49010, тел. +38 (063) 4929617 , эл. почта netesakostia@meta.ua, ORCID 0000-0002-4087-5552
\end{abstract}

\section{ОПРЕДЕЛЕНИЕ АСПЕКТОВ ОЦЕНКИ НАДЕЖНОСТИ ФАСАДНЫХ СИСТЕМ С ТОЧКИ ЗРЕНИЯ ЕUROCODЕ}

Цель. Работа посвящена определению наиболее рациональной методики оценки надежности фасадных систем многоэтажных жилых зданий с использованием опыта строительства и эксплуатации зданий за рубежом. Также предусматривается определение параметров материалов фасадных систем, улучшение которых позволит повысить надежность, долговечность фасадных систем многоэтажных жилых зданий и снизить стоимость их эксплуатации. Методика. В исследовании проведен сравнительный анализ опыта эксплуатации фасадных систем различных типов в Украине и за рубежом на основании данных разных авторов. Осуществлен анализ воздействия внешних факторов на фасадные системы с последующим сравнением методик оценки надежности фасадов по критериям, изложенным в Eurocode, и выделением параметров, определяющих надежность и долговечность фасадных систем. Результаты. Авторами проведены исследования методов оценки организационно-технологической надежности и долговечности современных фасадных систем. Были выявлены причины возникновения отказов фасадных систем. Предложены пути совершенствования материалов фасадных систем, а также конструкционных и организационно-технологических решений по устройству фасадных систем. Определены методы повышения надежности и долговечности фасадных систем. Научная новизна. Определена наиболее рациональная методика оценки надежности фасадных систем, учитывающая требования Eurocode в вопросах проектирования строительных конструкций. Практическая значимость. Усовершенствование методов оценки организационнотехнологической надежности фасадных систем многоэтажных жилых зданий позволит точнее прогнозировать срок службы ограждающих конструкций зданий. Использование методик, изложенных в Eurocode, для определения надежности и долговечности фасадных систем позволит обеспечить общие критерии проектирования строительных конструкций в Украине и странах Европы, а также облегчить обмен опытом строительства и эксплуатации зданий между странами Европы. Анализ причин возникновения отказов фасадов дает возможность определить направления совершенствования свойств материалов, используемых для изготовления элементов фасадных конструкций, а также конструкционных и технологических решений применяемых фасадных систем.

Ключевые слова: фасадная система; надежность; долговечность; эксплуатация; отказ

\section{REFERENCES}

1. Gagarin V.G. Teploizolyatsionnyye fasady s tonkim shtukaturnym sloyem [Insulating facades with a thin plaster layer]. $A V O K-A B O K, 2007$, no. 6, pp. 82-103.

2. Granovskiy A.V., Kiselev D.A. O metodike ispytaniy ankerov na vyryv iz razlichnykh stenovykh materialov i vozmozhnykh oblastyakh ikh primeneniya [The methodology of testing of anchors pull-out from a variety of wall materials and possible areas of their application]. Zhilishchnoye stroitelstvo - Housing Construction, 2010, no. 2, pp. 7-8.

3. DSTU-N B V.1.2-13:2008. Nastanova. Osnovy proektuvannia konstruktsii [DSTU-N.1.2-13:2008. Installation. Principles of design of structures]. Kyiv, Minrehionbud Ukrainy Publ., 2009. 81 p.

4. Dudkina V.V. Adgezionnaya prochnost nikelevykh i tsinkovykh pokrytiy s mednoy osnovoy, elektroosazhdennykh v usloviyakh vneshney stimulyatsii lazernym izlucheniyem [Adhesion strength of nickel and zinc coatings with copper base electroplated in conditions of external stimulation by laser irradiance]. Nauka ta prohres transportu. Visnyk Dnipropetrovskoho natsionalnoho universytetu zaliznychnoho transportu - Science and Transport Progress. Bulletin of Dnipropetrovsk National University of Railway Transport, 2013, no. 2 (44), pp. 83-91. doi: 10.15802/stp2013/12245. 
5. Yemelyanova V.A., Nemova D.V., Miftakhova D.R. Optimizirovannaya konstruktsiya navesnogo ventiliruemogo fasada [Optimized design of hinged ventilated facades]. Inzhenerno-stroitelnyy zhurnal - Journal of Civil Engineering, 2014, no. 6 (50), pp. 53-66.

6. Yenotkina S. Ekspluatatsiya mnogosloynykh ograzhdayushchikh konstruktsiy [Operation of multilayer walling]. Molodoy uchenyy - Young Scientist, 2011, no. 6 (29), pp. 49-52.

7. Motyaev M.A. Azbuka navesnykh fasadov s vozdushnym zazorom [The ABC of suspended facades with air gap]. Saint-Petersburg, Yukon Inzhiniring Publ., 2005. 104 p.

8. Orlovich R.B., Rubtsov N.M., Zimin S.S. O rabote ankerov v mnogosloynykh ograzhdayushchikh konstruktsiyakh s naruzhnym kirpichnym sloyem [On the work of anchors in multilayer constructions with outer brick layer]. Inzhenerno-stroitelnyy zhurnal - Journal of Civil Engineering, 2013, no. 1 (36), pp. 3-11.

9. Tereshkova A.V. Issledovaniye deformativnosti $i$ sovershenstvovaniye konstruktivnykh resheniy elementov karkasa fasadnykh sistem s ventiliruyemym vozdushnym zazorom. Dok. Diss. [The study of deformation and improvement of design solutions of the frame elements of facade system with ventilated air gap. Doct. Diss.]. Krasnoyarsk, 2007. 233 p.

10. Tusnina O.A., Yemelyanov A.A., Tusnina V.M. Teplotekhnicheskiye svoystva razlichnykh konstruktivnykh sistem navesnykh ventiliruemykh fasadov [Thermal properties of various structural systems of ventilated facades]. Inzhenerno-stroitelnyy zhurnal - Journal of Civil Engineering, 2013, no. 8 (43), pp. 54-63.

11. Shcherbak A.S. Issledovaniye svoystv sovremennykh teploizolyatsionnykh materialov [Research of properties of modern heat-insulation materials]. Nauka ta prohres transportu. Visnyk Dnipropetrovskoho natsionalnoho universytetu zaliznychnoho transportu - Science and Transport Progress. Bulletin of Dnipropetrovsk National University of Railway Transport, 2013, no. 2 (44), pp. 136-143. doi: 10.15802/stp2013/12993.

12. Dagnall M., Window A., Leung A., Thompson D. Analytical assessment of thermal performance of a ventilated glazed facade system. Proc. of Building Simulation : $12^{\text {th }}$ Conf. of Intern. Building Performance Simulation Association (14.11.-16.11.2011). Sydney, 2011, pp. 808-815.

13. Ciampi M., Leccese F., Tuoni G. On the thermal behavior of ventilated facades and roofs. La Termotecnica, 2002, no. 1, pp. 87-97.

14. Ciampi M., Leccese F., Tuoni G. Some thermal parameters influence on the energy performance of rhe ventilated walls. Proc. of $20^{\text {th }}$ UIT National Heart Transfer Conf. (27.06.-29.06.2002). Maratea, 2002, pp. 357-362.

Prof. V. D. Petrenko, D. Sci. (Tech.), (Ukraine); Prof. I. A. Sokolov, D. Sci. (Tech.) (Ukraine) recommended this article to be published

Received: June 15, 2015

Accepted: Aug. 14, 2015 